\title{
REDESCRIPTION OF CERCARIA YOSHIDAE CORT ET NICHOLS, 1920, A CYSTOPHOROUS CERCARIA IN \\ THE SNAIL SEMISULCOSPIRA SPP. IN JAPAN
}

\author{
JIRO ITO \\ The National Institute of Health \\ Tokyo, Japan \\ (Received: June 24, 1952)
}

Several Japanese investigators have described of the cystophorous cercaria from snails, Semisulcospira spp. in Japan, and its first description was made by Osafune (1899)(11), who recovered it in Okayama Prefecture. Seno $(1903)^{(12)}$, Miyagawa(1913)(9) and Ando $(1915,1918)^{(1,2)}$ have also made its descriptions later respectively, but these were very incomplete. Following these reports, Yoshida $(1917)^{(16)}$ made a more detailed description of this cercaria which is called "Cercaria F" by him, obtained in various areas in Japan, and Cort and Nichols $(1920)^{(3)}$ named it Cercaria yoshidae. During the past few years the author have recovered many Semisulcospira spp. in various areas in Japan, some of which are from the same spots where Yoshida has collected it before. These snails are parasitized with some 18 species of trematode larvae, one of which being a cystophorous cercaria presented here. In the following chapter, its morphology, geographical accounts and seasonal distributions in detail are reported.

\section{MATERIALS AND METHODS}

Three snail hosts harbored this cercaria, i. e. Semisulcospira libertina, S. reiniana and S. japonica. Cercariae were obtained by crushing these snail hosts or by making them to emerge from the host in natural way. Living materials taken in $0.4 \% \mathrm{NaCl}$-solution are most convenient for observing its detailed structure, especially its excretory system. Vital staining with neutral red and nile blue sulphate is helpful for detecting the alimental canal. The measurement was taken on materials fixed in $10 \%$ hot formalin. 
FEDIA (Fig. 5)

An infected snail harbors as a rule many mature and immature rediae in its midgut gland. They are ellipsoidal or fusiform in shape and elongated in its posterior end and move actively. They have neither collar nor locomotive appendix. Twenty materials fixed freely in 10\% hot formaline measured $0.69-1.76 \mu$ (av. $1.09 \mu$ ) in length, $0.19-0.32 \mu$ (av. $0.26 \mu$ ) in width. The body surface at the anterior part is beset with many minute spines and sensory hairs. These minute spines are arranged in row following with the next row alternately and are most dense at the margin of its mouth. The sensory hairs, with the length of $1.5 \mu \mathrm{ca}$. which can only be recognizable with great effort, are beset on a minute papilliform base respectively outside the mouth. A well developed pharynx is situated at the anterior end of redia. Its length is $51.9-64.1 \mu$ (av. $58.7 \mu$ ) and the width is $39.7-58.0 \mu$ (av. 48.1 $\mu$ ). A long intestine, which follows directly the pharynx, occupies about two thirds of the length of

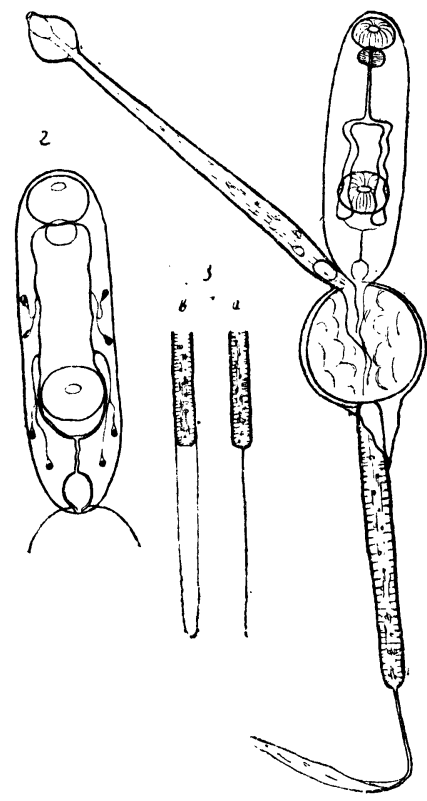

F'ig. 1. Cercaria yoshidae, obtained by crushing the snail host.

Fig. 2. The excretory system of the body.

Fig. 3. Posterior end of the tail, a, dorsal view, b, lateral view.

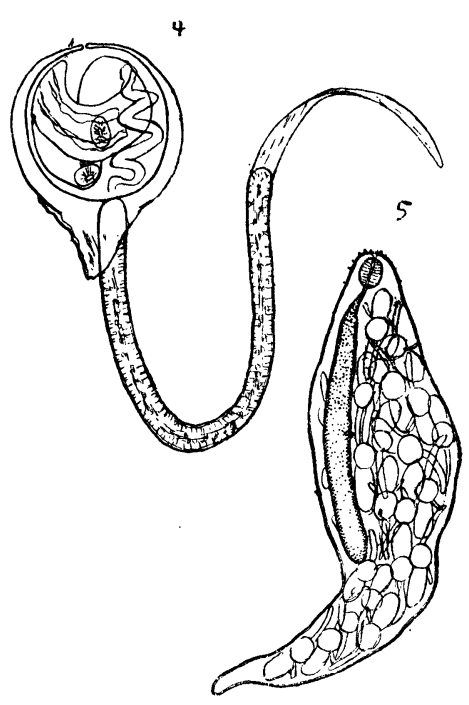

Fig. 4. Cercaria yoshidae, free emerging cercaria from the host.

Fig. 5. Mature redia. 
redia and contains many brownish fragments. A birth pore opens near the side of the pharynx of redia. In the body cavity, about $20-30$ cercariae of various developmental stages and many small germinal masses are contained.

\section{CERCARIA. (Fig. 1, 2, 3 and 4)}

The cercaria belongs to cystophorous group of Sinitsin (1911). The measurements of twenty cercariae fixed in $10 \%$ hot formalin are as follows:

$$
\begin{aligned}
& \text { Body . . . . . . . . 152.5-247.1 (av. 207.9) } \times 45.8-58.0 \text { (av. 54.2) } \mu \\
& \text { Pharynx . . . . . . 12.2-18.3 (av. 14.1) } \times 24.4-27.5 \text { (av. 25.9) } \mu \\
& \text { Oral sucker . . . . . 27.5-30.5 (av. 29.0) } \times 33.5-36.6 \text { (av. 35.5) } \mu \\
& \text { Ventral sucker . . . . 30.5-36.6 (av. 33.9) } \times 33.5-36.6 \text { (av. 35.8) } \mu \\
& \text { Cyst (Cavity) . . . . 85.4-91.5 (av. 86.5) } \mu \text { in diameter. } \\
& \text { Delivery tube. . . . . 143.4-381.7 (av. 314.3) } \times 13.7-21.3 \mu \\
& \text { Tail . . . . . . . 280.6-396.5 (av. 362.9) } \times 16.8-19.8 \text { (av. 18.3) } \mu
\end{aligned}
$$

The body is ellipsoidal in shape, entirely aspinous on its body surface. The body is colorless and very transparent because it has neither penetration glands nor cystogenous gland cells. A comparatively large oral sucker is situated at the anterior end. A slightly larger ventral sucker is situated at the two thirds posteriorly of the body. The oral sucker is directly followed with a pharynx without prepharynx. An esophagus runs backwards from the pharynx and divides into two intestines at the middle of the body. These intestines reach behind the ventral sucker ending in blind. This intestine is difficult to see in raw materials but easily recognizable in vitally stained specimens with neutral red. An excretory bladder is globular in shape situating at the end of the body. From its anterior median point one collecting tube runs forewards, bifurcating into lateral collecting tubes behind the ventral sucker. These tubes run forwards respectively at the side of the body and are connected each other just behind the oral sucker. On the way of these collecting tubes, there are two pairs of branches, each of which received two flame cells respectively as figured in Fig. 2. The flame cell measures about $6.6 \times 2.7 \mu$ and can easilly be recognized. Thus the flame cell formula is represented by $2 \times[(2+2)]$, as same in Cercaria yokotei Komiya 1942 and another related species. 
Between the body and the tail, a large globular cavity, which is called "cyst" by Sewell (1922) or “bulbus" by Faust (1922) is situated. This cyst is composed of two layers of hyaline membrane and contains a parenchymal and a tubular structure. From the anterior corner of this cyst, a long delivery tube is projected antero-obliquely. The distal end of this tube swells up to form a small cavity measuring about $52 \times 37 \mu$. The structure mentioned above is, however, only seen in immature form obtained by crushing the snail, and in the mature form sheded in natural way, the body and the delivery tube are found introverted in the cyst above mentioded as shown in Fig. 4. The latter swims vigorously by the aid of a tail. A strongly developed tail is peculiar in its shape, namely, its posterior one third becomes flat laterally to form a fin or oar shape as figured in Fig. 3.

\section{GEOGRAPHICAL AND SEASONAL DISTRIBUTION}

The infectivity rate of the snail hosts with this cercaria in several areas in Japan are shown in Table 1, as has been observed during 6

Table 1. The geographical distribution of Cercaria yoshidae in Japan

\begin{tabular}{|c|c|c|c|c|c|}
\hline Locality & Snail host & Date & \begin{tabular}{|c|} 
Number \\
examined
\end{tabular} & $\begin{array}{l}\text { Number } \\
\text { infected }\end{array}$ & $\begin{array}{l}\text { Percent- } \\
\text { age }\end{array}$ \\
\hline $\begin{array}{l}\text { Edo River } \\
\text { Tokyo }\end{array}$ & S. reiniana & $\begin{array}{l}\text { Oct. } 1946- \\
\text { Sept. } 1948\end{array}$ & 1488 & 69 & $4.64 \%$ \\
\hline $\begin{array}{c}\text { Nameri River } \\
\text { Kanagawa }\end{array}$ & S. libertina & July 1950 & 130 & 0 & - \\
\hline$\underset{\text { Yakakoma-gun }}{\text { Yamanashi }}$ & S. libertina & $\begin{array}{l}\text { May } 1947-\overline{1} \\
\text { May } 1951\end{array}$ & 1892 & 3 & $0.16 \%$ \\
\hline $\begin{array}{c}\text { Kano River } \\
\text { Shizuoka }\end{array}$ & S. libertina & $\begin{array}{l}\text { Oct. } 1948- \\
\text { Nov. } 1950\end{array}$ & 9240 & 30 & $0.31 \%$ \\
\hline$\underset{\text { Kochi }}{\text { Hatta-gun }}$ & S. japonica & $\begin{array}{l}\text { Jan. } 1950- \\
\text { Feb. } 1950\end{array}$ & 882 & 9 & $0.10 \%$ \\
\hline Ehime & S. japonica & May 1949 & 546 & 0 & 一 \\
\hline \multicolumn{3}{|c|}{ Total } & 14578 & 111 & $0.76 \%$ \\
\hline
\end{tabular}

years 1946-1951. The highest infectivity rate was observed in the snails from Edo River running the suburbs of Tokyo, and in other localities, on the other hand, proved rather low infestations. Seasonal fluctuations in the infection of snails with this cercaria observed in Tokyo, Shizuoka 
and Yamanashi Prefectures are as shown in Table 2. As seen in Table 2 , no clear relationship seems to exist between the infectivity rate and

Table 2. The seasonal distribution of Cercaria yoshidae in Japan

\begin{tabular}{|c|c|c|c|c|}
\hline Locality & Date & $\begin{array}{l}\text { Number } \\
\text { examined }\end{array}$ & $\begin{array}{l}\text { Number } \\
\text { infected }\end{array}$ & Percentage \\
\hline \multirow{9}{*}{$\begin{array}{l}\text { Edo River } \\
\text { Tokyo }\end{array}$} & Oct. 1946 & 301 & 16 & $5.31 \%$ \\
\hline & Dec. $\quad "$ & 300 & 10 & $3.33 \%$ \\
\hline & Apr. 1947 & 21 & 1 & $4.78 \%$ \\
\hline & July " & 218 & 7 & $3.21 \%$ \\
\hline & Sept. " & 102 & 6 & $5.88 \%$ \\
\hline & Mar. 1948 & 100 & 3 & $3.00 \%$ \\
\hline & May " & 208 & 10 & $4.80 \%$ \\
\hline & July $\quad$, & 134 & 7 & $5.22 \%$ \\
\hline & Sept. " & 104 & 9 & $8.65 \%$ \\
\hline \multirow{13}{*}{$\begin{array}{c}\text { Kano River } \\
\text { Shizuoka }\end{array}$} & Oct. 1948 & 755 & 1 & $0.13 \%$ \\
\hline & Nov. " & 1497 & 3 & $0.20 \%$ \\
\hline & Jan. 1949 & 1601 & 8 & $0.50 \%$ \\
\hline & Mar. " & 507 & 5 & $0.99 \%$ \\
\hline & Apr. $"$ & 492 & 7 & $1.42 \%$ \\
\hline & June $\quad$ & 161 & 0 & - \\
\hline & July " & 814 & 0 & - \\
\hline & Sept. " & 1012 & 0 & - \\
\hline & Oct. " & 567 & 2 & $0.35 \%$ \\
\hline & Nov. " & 901 & 3 & $0.33 \%$ \\
\hline & May 1950 & 689 & 1 & $0.14 \%$ \\
\hline & Sept. " & 144 & 0 & - \\
\hline & Nov. " & 500 & 0 & - \\
\hline \multirow{5}{*}{$\begin{array}{c}\text { Nakakoma-gun } \\
\text { Yamanashi }\end{array}$} & May 1947 & 207 & 0 & - \\
\hline & June " & 85 & 0 & - \\
\hline & Oct. $\quad "$ & 555 & 1 & $0.180^{\circ}$ \\
\hline & Nov. " & 727 & 2 & $0.28 \%$ \\
\hline & May 1951 & 318 & 0 & - \\
\hline
\end{tabular}

the seasons. Table 3 shows the percentage of infectivity rate with the cercaria in relation to the size of snail host, which indicates that the larger is the host, the greater is the possibility of harboring the cercaria. 
Table 3. Correlation of infectivity rate of $C$. yoshidae with the length of snail host.

\begin{tabular}{|c|c|c|c|}
\hline $\begin{array}{c}\text { Length of } \\
\text { snail host }\end{array}$ & $\begin{array}{c}\text { Number } \\
\text { examined }\end{array}$ & $\begin{array}{c}\text { Number } \\
\text { infected }\end{array}$ & Presentage \\
\hline Under $10 \mathrm{~mm}$ & 337 & 0 & - \\
$11-15 \mathrm{~mm}$ & 1100 & 2 & $0.18 \circ^{\circ}$ \\
$16-20 \mathrm{~mm}$ & 2165 & 5 & $0.28 \circ^{\circ}$ \\
$21-25 \mathrm{~mm}$ & 3841 & 24 & $0.63 \circ^{\circ}$ \\
$26-30 \mathrm{~mm}$ & 3766 & 43 & $1.14 \%$ \\
$31-35 \mathrm{~mm}$ & 2021 & 20 & $0.99 \circ^{\circ}$ \\
$36-40 \mathrm{~mm}$ & 821 & 17 & $2.06 \%$ \\
\hline Total & 14051 & 111 & $0.79 \circ^{\circ}$ \\
\hline
\end{tabular}

\section{DISCUSSIONS}

So far as the original descriptions of Osafune $(1899)^{(11)}$, Senoo $(1903)^{(12)}$, Miyagawa $(1913)^{(9)}$, Ando $(1915,1918)^{(1,2)}$ and Yoshida $(1917)^{(16)}$ indicate, these cercariae seem to be much the same species identical to the cercaria described herewith. Cort and Nichlos $(1920)^{(3)}$ named it Cercaria Yoshidae reffering to his description of C. californiensis. In 1922, Kobayashi summarized the above-mentioned cercariae, as Cystophora A, including Cercaria XIII of Nakagawa $(1915)^{(10)}$ obtained in Formosa, and Faust (1924) named it Cercaria paracaliforniensis without meeting with any discussion. According to Nakagawa's original description, however, his species seems to be something another, because his measurements are about twice as large as $C$. yoshidae. Fukui and Shimizu (1936)(7) reported later on one cystophorous cercaria from the same host in Japan, which seems to be the same species of $C$. yoshidae. Cercaria VIII reported by Yokogawa and Wakeshima $(1934)^{(15)}$ in Formosa resembles to Nakagawa's species.

About twenty species of cystophorous cercariae have been recorded in the world. Cercaria invaginata Faust, 1924 in snail Melania canceblata in China is the most closely related species to this cercaria, but his measurements are much smaller than the present species and excretory system is in different type.

It seems to be reasonable that the cystophorous cercariae reported by several Japanese workers in Japan are the one summarized and called Cercaria yoshidae Cort et Nichols, 1920. Cystophorous cercaria A of 
Kobayashi $(1922)^{(6)}$ ought to have been divided into two species, and the name Cercaria paracaliforniensis of Faust $(1924)^{(5)}$ considered as a synonym of C. yoshidac.

Tsunoda $(1950)^{(13)}$ have recently reported of its life cycle. According to him, the second intermediate host is various species of smaller copepodes, by which the cercariae are eaten passively. He failed to get the adult worm but suggested it to develop into the member of genus Halipegus of Hemiuridae in the small fresh water fishes of Gobiidae.

Author's acknowledgements and indebtedness are due to Dr. Y. Komiya, the Chief of the Parasitology Division, National Institute of Health for his generous encouragement and reviewing the original manuscript.

\section{REFERENCES}

1. Ando, R.: On the new endemic area of lung fluke in Gifu Prefecture, and study on its intermediate host and metacercaria. Nippon Byori Gakkai Zasshi, 5, 125-128, 1915 (in Japanese).

2. Ando, R.: Studies on the cercariae of Melania libertina from an endemic area of lung fluke in Gifu Prefecture (Addition of 6 species of cercariae). Chuo Igaku Zasshi, 141, 610, 1918 (in Japanese).

3. Cort, W.W. and Nichols, E.B.: A new cystophorous cercaria from California. Jour. Parasitol., 7, 8-15, 1920.

4. Dollfus, R.Ph.: Hôtes et distribution gêographique des cercaires cystophores. Ann. Parasitol. Humaine et Comp. 25, 276-296, 1950.

5. Faust, E.C.: Notes on larval flukes from China, II. Studies of some larval fluke from the Central and South Coast Provinces of China. Amer. Jour. Hyg., 4, 241-301, 1924.

6. Kobayashi, H.: A review of Japanese cercariae. Dobutsugaku Zasshi, 34, 252-270. 1922 (in Japanese).

7. Fukui, T. and Shimazu, M.: Studies on the seasonal fluctuation of cercariae of Melanoides (Smisulcospira) libertina, and of its reproduction. Dobutsu Seitaigaku Zasshi, 1, 1-8, 1936 (in Japanese).

8. Komiya, Y.: A new cystophorous cercaria, Cercaria yokotei, and its excretory system. Jour. Shangh. Sci. Inst. Sect. IV. 1, 121-127, 1942.

9. Miyagawa, Y.: Studies on the cercaria and young adult of Schistosoma japonicum. Iji Shinbun, 890, 1-11, 891, 5-16, 1913 (in Japanese).

10. Nakagawa, K.: On the cercariae of fresh water snail in Shinchiku Province, Formosa. Taiwan Igakkai Zasshi 148, 107-120, 1915 (in Japanese)

11. Osafune, K.: Studies on the development of Clonorchis sinensis. Okayama Igakkai Zasshi 107, 347-356, 108, 8-12, 1899 (in Japanese).

12. Senoo, H.: Studies on cercariae, I. Dobutsugaku Zasshi, 15, 1-5, 1903 (in Japanese)

13. Tsunoda, K.: On the life history of one cystophorous cercaria parasitic in Semisulcospira sp. Annual report of Society of Parasitology of Japan 19, 27-28, 1950, (in Japanese). 
14. Willey, C.H.: A cystophorous cercaria, C. projecta n. sp., from the snail, Helisoma antrosa, North America. Parasitol., 22, 481-489, 1930.

15. Yokogawa, S. and Wakeshima, T.: On the cercariae of Melania libertina from an endemic area of lung fluke in Shinchiku Province, Formosa, 33, 875-876, 1934 (in Japanese).

16. Yoshida, S.: Studies on the cercariae of Melania spp. Dobutsu gaku Zasshi, 29, (342), 1-17, 1917 (in Japanese). 